\title{
Spade Leaf Extract Phytosome Modulates Krox-20, Neuregulin_I, Phospholipids, and Cognitive Function of Traumatic Brain Injury Model in Rats
}

\author{
Alif Fariz Jazmi ${ }^{1}$, Putri Fitri Alfiantya ${ }^{1}$, Sitti Ayu Hemas Nurarifah ${ }^{1}$, Erlin Aditia \\ Purmitasari $^{2}$, Lilin Andreas Vitania ${ }^{2}$, Wibi Riawan ${ }^{3}$ \\ ${ }^{1}$ Undergraduate Program of Physician, Faculty of Medicine, Brawijaya University, Malang, Indonesia \\ ${ }^{2}$ Undergraduate Program of Pharmacy, Faculty of Medicine, Brawijaya University, Malang, Indonesia \\ ${ }^{3}$ Biochemistry and Biomolecular laboratory, Faculty of Medicine, Brawijaya University, Malang, Indonesia
}

\begin{abstract}
Traumatic brain injury (TBI) is a disorder of the central nervous system due to head trauma. TBI can damage nerve membrane phospholipids and decrease protein synthesis of neuregulin-I (NRG-I) because of the transcription factor Krox-20. These conditions cause the lowering in nerve re-myelination which contribute to the decline of cognitive function. In Indonesia, citicoline is a neuroprotective drug that widely used to repair and prevent further damage of the nerve cells membrane caused by trauma. Spade leaf (Centella asiatica) extract phytosome (SEP) is a model of drug delivery system which expected to enhance the therapeutic effects as neuroprotective drug. This study aims to demonstrate and compare the effectiveness from SEP and citicoline as a neuroprotective characterized by increasing the activation of Krox-20, the expression of NRG-I, the distribution of phospholipids, and the improvement of cognitive levels on TBI-induced rats. Rats were divided into 5 groups namely: control (-); control (+); treatment with SEP $90 \mathrm{mg} / \mathrm{kgBW}$; citicoline $250 \mathrm{mg} / \mathrm{kgBW}$, and SEP in combination with citicoline. Krox-20, NRG-I, and phospholipids expression were measured by immunohistochemical assay, while cognitive function were assessed with the Morris Water Maze test. According to ANOVA test results, it was showed that SEP improved the nerve cells through the activation of Krox-20, NRG-I expression, and distribution of phospholipids significantly $(p<0.05)$. Based on Morris Water Maze test, SEP also improved the cognitive function in TBI-induced rats. Thus, it can be concluded that spade leaf extract phytosome combined with citicoline increase a higher phospholipids distribution and give the fastest time in the cognitive tests compared with of spade leaf extract phytosome and citicoline alone.
\end{abstract}

Keywords : NRG-I, Krox-20, phospholipids, phytosome, Centella asiatica.

\section{INTRODUCTION}

Traumatic Brain Injury (TBI) is an immediate mechanical damage of the nerve tissue and becomes the leading cause of mortality and morbidity both in developed and developing countries (Albert-Weissenberger and Sirén, 2010). Around 1.7 million people in United States are approximated to suffer from TBI every year (Faul, et al., 2010).

About $53.4 \%$ people in Indonesia, particularly in Jakarta, suffer relatively severe head injuries from an accident (Riyadina, et al., 2009). Recent study has shown that there was axonal degeneration occurred in the brain after the incidence of TBI. Axonal damage causes decrease in Neuregulin-1 (NRG-1) protein synthesis that leads to neural myelination failure.

Spade leaf (Centella asiatica) is a medicinal herb and usually can be found widely in Indonesia. Spade leaf extract is known to exhibit neuroprotective effect through adding myelin thickness (Alfiantya, et al., 2014). However, phytochemical component of spade leaf are relatively polar, thus it is needed to enhance pharmacokinetic profile by using phytosome (Sharma and Roy, 2010). Therefore, it is essential for this study to elaborate an innovation of spade leaf extract in formulation to phytosome.

\footnotetext{
*Corresponding author e-mail: fariztoon@gmail.com
} 
Meanwhile, citicoline is still the main neuroprotector that majorly used in Indonesia. Citicoline is known to exhibit capability in repairing and preventing further nerve traumatic damage through distribution of phospholipid membrane (Baker, et al., 2002). Thus, this research is carried on to develop innovation of spade leaf extract in phytosome as a neuroprotective agent compared to citicoline as the current neuroprotector standard.

\section{MATERIALS AND METHODS}

\section{Sample Preparation Characterization}

and

As many as $400 \mathrm{mg}$ powdered herb were soaked with $500 \mathrm{~mL}$ of $70 \%$ ethanol and stirred mildly in a macerator for 30 minutes. Contents were kept for 24 hours by shaking and stirring and continued to be remacerated. The whole mixture was filtrated, then filtrate was evaporated by using rotary evaporator (at $30^{\circ} \mathrm{C}$ ) and was vacuum dried to eliminate water content (Adianingsih, et al., 2013; Pramono and Ajiastuti, 2004). This viscous extract was made into phytosome through sonication by adding with lecithin and $70 \%$ ethanol, then stirring constantly for 3 hours at $2000 \mathrm{rpm}$ by using magnetic stirrer. Solvent was evaporated with rotary evaporator and hydrated with $\mathrm{CO}_{2}$-free water. Characterization of phytosome was carried out by using TEM (Adianingsih, et al., 2013).

\section{In vivo Assay}

This study was done with in vivo by randomized post test only controlled group design in male rats (Rattus norvegicus) aged 45 months and weighed 200-300 grams. Rats were divided into 5 groups: rats without any treatments; rats induced with TBI without any treatments; rats were induced with TBI and treated with spade leaf extract phytosome (SEP) $90 \mathrm{mg} / \mathrm{kgBW}$; rats induced with TBI and treated with citicoline $250 \mathrm{mg} / \mathrm{kgBW}$; rats were induced with TBI and treated with both phytosome and citicoline as mentioned above. Spade leaf extract phytosome and citicoline were injected into peritonioum every day.

The third day after TBI inducement, surgery was carried out on half number of every group to evaluate Krox-20 activation, NRG-1 protein expression, and phospholipid distribution. The remaining half number were evaluated to cognitive function test 28 day after TBI inducement.

Traumatic Brain Injury (TBI) inducement was conducted as follows, rats were anesthetized with xyla $(5 \mathrm{mg} / \mathrm{kgBW})$ and ketamine $(50 \mathrm{mg} / \mathrm{kgBW})$ by intraperitoneal injection. The head fur was shaved and then wiped with $70 \%$ ethanol. A 45-gram metal cylinder (4 $\mathrm{mm}$ in diameter) was dropped by the angle of $90^{\circ}$ from the height $100 \mathrm{~cm}$ once. Ten minutes after the inducement, rats of each selected group were treated with spade leaf extract phytosome, citicoline, or their combination.

\section{Cognitive Function Test}

Cognitive function test was conducted as follows: a pool was designed (1 meter in diameter, 0.25 meter depth) then filled with water at $22-24^{\circ} \mathrm{C}$ temperature and a plastic floater (10 centimeter in diameter) placed perpendicularly towards the position of the rat. Rat was let free at one side of the pool (opposing the floater) for 60 seconds to swim and track the exact position of the floater. Then rat was taken back to its initial position and the time needed for rat to swim and again reach the floater was recorded. The test was performed three times for each rat. Cognitive function was assessed as a quantitative analysis of time length needed for rat to reach the floater (Thompson, et al., 2006).

The brain tissue was taken during surgery was deparaffinized then kept for 24 hours before proceeded to immunohistochemistry assay. This stained tissue sample was observed for Krox-20 activation, NRG-1 protein expression, and phospholipid distribution by using Olympus CX21 microscope at 40x objective magnification and 10 field of view for each slide.

\section{Data Analysis}

Results were analysed statistically with SPSS Statistics at 0.05 significance level and 95\% confidence level. The hypothetical comparative and correlative tests include normality test, variant homogenity test, oneway ANOVA test, post hoc, and Pearson correlation test (Dahlan, 2004).

\section{RESULT AND DISCUSSION}

As many as 400 gram of spadeleaf powder were macerated into 83.8 gram of crude 
extract. The Spadeleaf crude extract then formulated to phytosome and its characterization was obtained. Fig. 1. The visualization of phytosome of Spadeleaf extract by using TEM.

\section{Characterization of Crude Extract and Phytosome of Spadeleaf Extract}

The visualization of particles with Transmission Electron Microscopy (TEM) was used to visualize the morphology and characterize the particle size from phytosome of Spadeleaf extract. From the visualization by using TEM, the size of phytosome particle was 20-100 nm and based on its morphology, also it was shown that the particle was formed into lipid monolayer. Based on its size particle, the phytosome could be categorized as Small Unilamellar Vesicle (SUV) (Sulistiyani, 2014).

\section{Qualitative analysis for Spadeleaf extract} by using Thin Layer Chromatography

Qualitative phytochemical screening of spadeleaf extract was done by using Thin Layer Chromatography (TLC) (Fig. 2). The data showed that there was a spot in Rf: 0,2750 . This score was near with its standard of asiaticoside which located in $\mathrm{Rf}=0,2875$. According to Wagner (1996), the spot of asiaticoside was located in $\mathrm{Rf}=0.2-0.35$. Thus, asiatiocotide was identified qualitatively in $70 \%$ ethanolic spadeleaf extract.

\section{Quantitative analysis with Liquid Chromatography - Mass Spectra/Masss Spectra (LC-MS)}

Asiaticoside level was obtained by using LCMS (Fig. 3). Based on this test, spadeleaf crude ethanolic extract was contained $0.232 \%$ of asiaticoside.

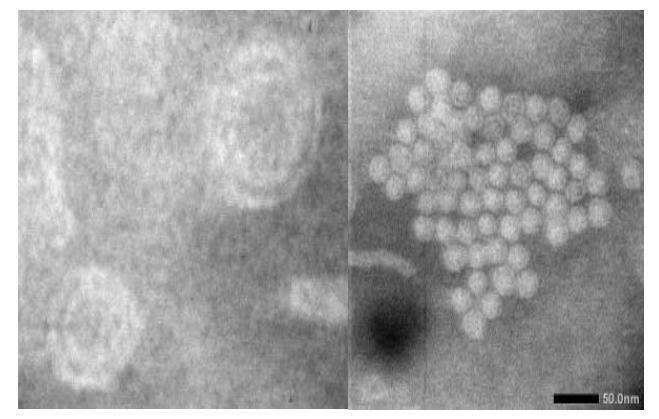

Figure I. Morphology visualization and particle size of phytosome

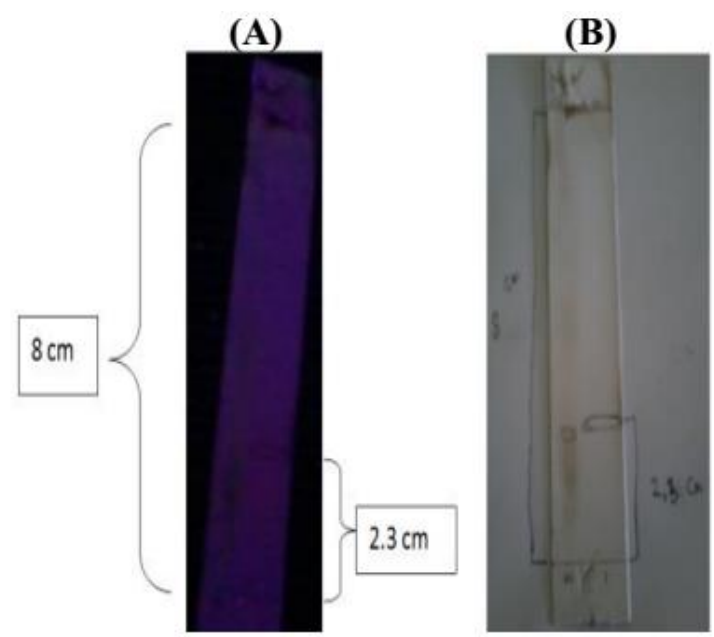

Figure 2. TLC plate visualization in UV (A) and visible (B) 


\section{Cognitive Function Score}

From Morris Water Maze result, based on Fig. 3, the data showed that from memory test, all treatment groups were getting shorter time which indicate that the memory of the rats were sharper in remembering the object location. Although the time were hugely decreased, the positive control did not reach less than 11 minutes. In contrast, the group who treated with combination of Gotu kola phytosome and citicoline gave huge reduction time and also reach shortest amount of time (5 minutes).

\section{Distribution of Phospolipid, Expression of NRG-I, and Activation of Krox-20}

ANOVA test was obtained for distribution of phospolipid, expression of NRG1 , and activation of Krox-20 statistically which showed the score were $p=0(p<0.05)$. It means that at least there were at least 2 groups showed significant difference. Thus, post hoc Tukey HSD was obtained to know the difference among the groups. Based on post hoc test, the data showed there were significant difference in positive control with treated group 1 and 3 for expression of NRG-1 and activation of Krox20. Meanwhile, there was a significant difference between positive control with treated group 1,2 and 3 in distribution of phospholipid (Fig.4 and Table 1).

\section{Characterization of Phytosome of Spadeleaf Extract}

Qualitative analysis with TLC can be seen from the spot and $\mathrm{Rf}$ score, where two compounds were identical if have same $\mathrm{Rf}$ score in same TLC condition (stationary phase and mobile phase). In this study, the Rf score of asiaticoside standard was 0.2875 and $\mathrm{Rf}$ score from literature was 0.2-0.35 (Wagner and Bladt, 1996).

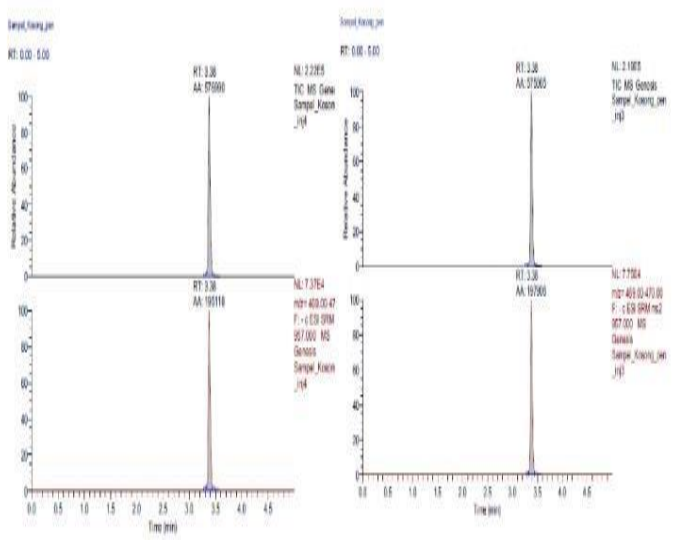

Figure 3. Chromatogram and Fragmentation from LC/MS
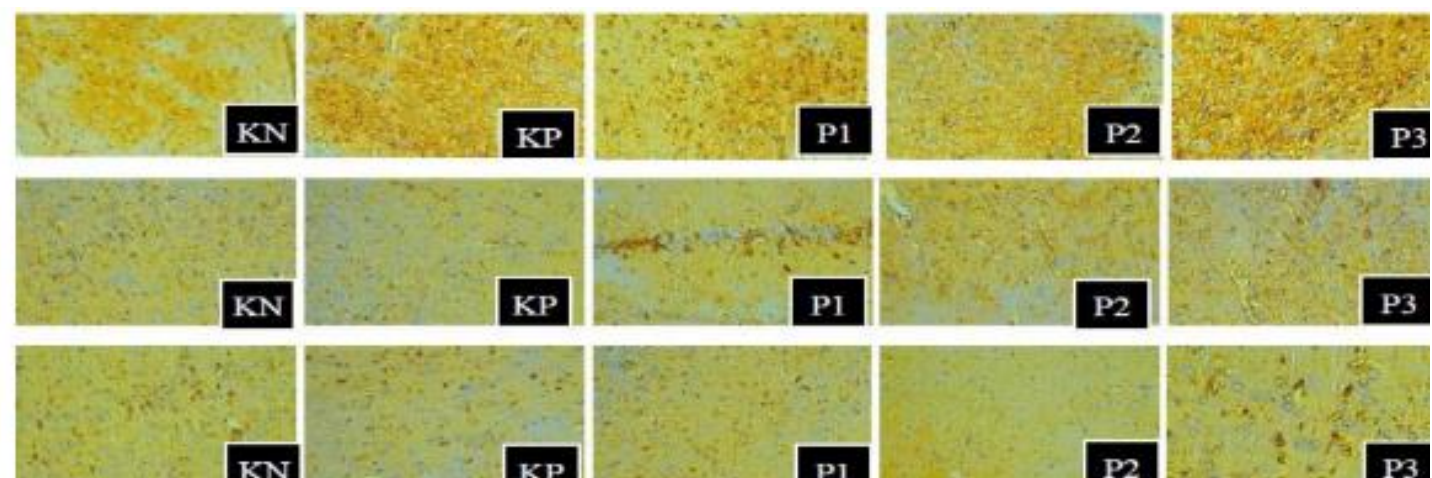

$\mathbf{K N}$
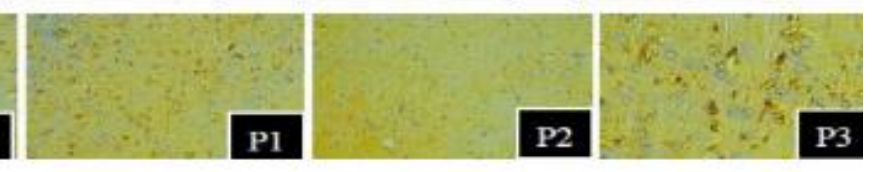

Figure 4. Phospolipid (top), Krox-20 (middle), NRG-I (down) histopathology observation from brain tissue using immunohistochemistry. KN (control group); KP (TBI-induced); PI (TBI-induced + phytosome 90mg/kgBW); P2 (TBI-induced + CDP-choline $250 \mathrm{mg} / \mathrm{kgBW}) ; \mathrm{P} 3$ (TBI-induced + phytosome $90 \mathrm{mg} / \mathrm{kgBW}+\mathrm{CDP}$-choline $250 \mathrm{mg} / \mathrm{kgBW})$. 
Table I. The distribution results of Phospolipid, NRG-I expression, and Krox-20 activation

\begin{tabular}{|c|c|c|c|c|c|c|}
\hline Variabel & Kelompok & $X$ & SD & Min & Max & $\mathbf{P}$ \\
\hline \multirow[t]{5}{*}{ Fosfolipid } & $\mathrm{KP}$ & 86,33 & 8,386 & 31 & 89 & \\
\hline & KN & 74.50 & 16,351 & 55 & 96 & \\
\hline & P1 & 19967 & 31,664 & 185 & 227 & $P=0,05$ \\
\hline & $P 2$ & 186,33 & 16,773 & 167 & 197 & $P=0,05$ \\
\hline & P3 & 220,25 & 17,689 & 203 & 236 & $F=0,05$ \\
\hline \multirow[t]{5}{*}{ NRC-1 } & $\mathrm{KP}$ & 72,33 & 6,110 & 57 & 96 & \\
\hline & $\mathrm{KN}$ & 72,25 & 17,858 & 58 & 98 & \\
\hline & P1 & 186 & $21, \sqrt{31}$ & 158 & 203 & $P<0,05$ \\
\hline & $P 2$ & 104,67 & 24,987 & 83 & 132 & $\mathrm{P}=0,203$ \\
\hline & P3 & 179 & 2,100 & 176 & 181 & $P \subset 0,05$ \\
\hline \multirow[t]{5}{*}{ Krox-20 } & $\mathrm{KP}$ & 72.67 & 11,590 & 65 & 86 & \\
\hline & $\mathrm{KI}$ & 67,25 & 19259 & 45 & 89 & \\
\hline & PI & 166,67 & 3,312 & 163 & 170 & Pe्,05 \\
\hline & P2 & 83,33 & 5,508 & 78 & 89 & $\mathrm{P}=0,899$ \\
\hline & P3 & 135,50 & 19,774 & 118 & 163 & $P \subset 0,05$ \\
\hline
\end{tabular}

These results indicated the presence of asiaticoside in phytosome so the concentration of asiaticoside can be done with LC-MS/MS assay where Phytosome of Gotu kola contained $0.232 \%$ of asiaticoside with $\mathrm{m} / \mathrm{z}=957.00$ that calculated for $\mathrm{m} / \mathrm{z}=469.54-470.89$.

\section{The mechanism of Neuron Recovery and Cognitive Function}

From this study, the treatment with phytosome of Gotu kola extract gave better result in increasing expression of NRG-1 and activation of Krox-20, compared to treatment with citroline alone. Based on ANOVA test, there was no significance between spadeleaf phytosome group and its combination with citroline group $(p>0.05)$. It was because spadeleaf extract phytosome had neuroprotective effect by improving nerve function in re-myelination of damaged nerve. Myelination started with the expression of NRG-1 by axon and it would interact with ErBb receptor in oligodendrocyte. The bonding between NRG-1 and ErBB would initiate cascade second messenger, started from increasing the accumulation of $\mathrm{Ca}^{2+}$, activation of the phosphatidylinositol-3-kinase (PI3K), focal adhesion kinase, and activation of mTOR kinase that caused the activation of myelin genes (Krox-20 \& P0) on oligodendrocyte cell nucleus (Taveggia, et al., 2010).

On the other hand, treatment with spadeleaf extract phytosome in combination with citicoline gave best result in increasing phospholipids distribution. It was because citicoline had neuroprotective effect in repairing damaged nerve by preventing the generation of free radicals. At first CDP-choline are broken down into choline and cytidine. Choline is metabolized in the body to produce CDP-choline, and with triacylglycerol phospholipids together will form the nerve cell membrane. The other mechanisms are CDPcholine, together with diglyceride will be metabolized into phosphatidylcholine and monoglyceride which prevents the formation of free fatty acids that will form free radicals (Zweifler, 2002).
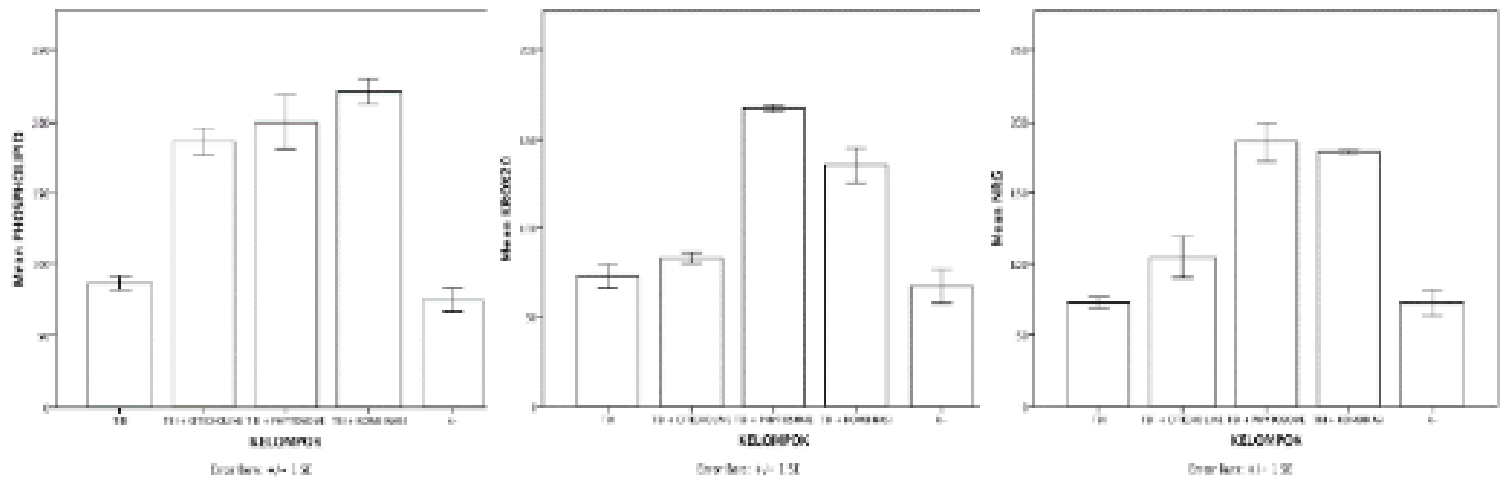

Figure 5. Graphic of average number of NRG-I in each treatment group 
The mechanism of spadeleaf extract phytosome for the distribution of phospholipids is not yet known, but the activation of Krox-20 gene is expected to trigger the formation of new phospholipids in nerve cells. Along with these results, from cognitive tests also showed a large reduction in time and gave the fastest time from treatment with combination compared to spadeleaf extract phytosome or citicoline alone.

Based on the results, it indicates the treatment with citicoline alone shows no significant difference in increasing the expression of NRG-1 and activation of Krox-2. Their combination can increase phospholipid distribution higher and give shortest time from cognitive test, compared to treatment with spadeleaf extract phytosome or citicoline alone.

\section{CONCLUSION}

Spade leaf extract phytosome in combination with citicoline increase a higher phospholipids distribution and give the fastest time in the cognitive tests compared with of spade leaf extract phytosome and citicoline alone.

\section{REFERENCES}

Albert-Weissenberger, $C$. and Sirén, A., 2010, Experimental Traumatic Brain Injury, Exp. Transl. Stroke Med., 2(I), 16.

Alfiantya, P. F., Adianingsih, O.R., Zulkarnaen, Jazmi, A. F., Nurarifah, S. A. H., dan Riawan, W., 2014, Phytosome Ekstrak Pegagan sebagai Modulator Neuregulin I pada Traumatic Brain Injury, JIMKI, 3(I), $32-39$.

Adianingsih, Sulistiyani, P., Zulkarnaen., Alfiantya P. F., and Agustin E. N. S., 2014, Characterization and Effect of Lotion Centella asiatica ExtractPhospholipid, BIMFI, 2(2), 7I-8I.

Baker, A.J., Phan,N., Moulton, R.J., Fehlings, M.G., Yucel, Y., Zhao, M., et al., 2002, Attenuation of the Electrophysiological Function of the Corpus Callosum After Fluid
Percussion Injury in the Rat, $J$. Neurotrauma., 19(5), 587-599.

Dahlan, M. S., 2004, Seri Statistik: Statistik untuk Kedokteran dan Kesehatan; Uji Hipotesis dengan Menggunakan SPSS Program 12 Jam, Jakarta: Arkans, 426.

Faul, M., Xu, L., Wald, M.M., and Coronado, V.G, 2010, Traumatic Brain Injury in the United States: Emergency Department Visits, Hospitalizations and Deaths 20022006, Atlanta (GA): Centers for Disease Control and Prevention, National Center for Injury Prevention and Control.

Pramono, S. dan Ajiastuti, D., 2004, Standarisasi Ekstrak Herba Pegagan (Centella asiatica (L.) Urban), Majalah Farmasi Indonesia, I5(3), 118-123.

Riyadina, W., Suhardi. and Permana, M., 2009, Pola dan Determinan Sosiodemografi Cedera Akibat Kecelakaan Lalu Lintas di Indonesia, Majalah Kedokteran Indonesia, 59, 464-72.

Sharma, S. and Roy, R. K., 2010, Phytosome: an Emerging Technology, Int. J. Pharmtech. Res., 2(5), I-7.

Sulistiyani, S., 20I4, Pengaruh Penambahan Kolesterol Terhadap Stabilitas Fisika dan Kimia Fitosom Ekstrak Pegagan (Centella asiatica), Essay, Program Studi Farmasi FKUB.

Thompson, H.J., LeBold, D.G., Marklund, N., Morales, D.M., Hagner, A.P. and Mclntosh, T. K., 2006, Cognitive Evaluation of Traumatically Braininjured Rats Using Serial Testing in the Morris Water Maze, Restor. Neurol. Neurosci., 24(2), 109-II4.

Taveggia, C., Feltri, M. L. and Wrabetz, L., 20I0, Signals to promote myelin formation and repair, Nature Rev. Neurol., 6, 276-287.

Wagner, H. and Bladt, S., 1996, Plant Drug Analysis: A Thin Layer Chromatography Atlas, 2nd Edition, Springer Publications, I56-162.

Zweifler, R. M., 2002, Membrane Stabilizer: Citicoline, Curr. Med. Res. Opin., 18(Suppl 2), I4-17. 